\title{
Correlations between spectral and biophysical data obtained in canola canopy cultivated in the subtropical region of Brazil
}

\author{
Daniele Gutterres Pinto(1), Denise Cybis Fontana(1), Genei Antonio Dalmago(2), Elizandro Fochesatto(3), \\ Matheus Boni Vicari(4), Carolina Bremm ${ }^{(5)}$, Gilberto Rocca da Cunha ${ }^{(2)}$, \\ Jorge Alberto de Gouvêa(2) and Anderson Santi(2)
}

\begin{abstract}
(1) Universidade Federal do Rio Grande do Sul, Departamento de Plantas Forrageiras e Agrometeorologia, Avenida Bento Gonçalves, no 7.712, Agronomia, CEP 91540-000 Porto Alegre, RS, Brazil. E-mail: daniele.gutterres@gmail.com, dfontana@ufrgs.br (2)Embrapa Trigo, Rodovia BR 285, Km 294, CEP 99050-970 Passo Fundo, RS, Brazil. E-mail: genei.dalmago@embrapa.br, gilberto.cunha@embrapa.br, jorge.gouvea@embrapa.br, anderson.santi@embrapa.br ${ }^{(3)}$ Faculdades Integradas do Vale do Iguaçu, Departamento de Agronomia, Padre Saporiti, no 717, Rio D’areia, CEP 84600-000 União da Vitória, PR, Brazil. E-mail: elizandrofochesatto@hotmail.com (4)University College London, Department of Geography, Gower Street, WC1E6BT, London, United Kingdom. E-mail: matheus_boni_vicari@hotmail.com ${ }^{(5)}$ Fundação Estadual de Pesquisa Agropecuária, Sede, Divisão de Pesquisa e Inovação Tecnológica, Gonçalves Dias, № 570, Menino Deus, CEP 90130-060 Porto Alegre, RS, Brazil. E-mail: carolina-bremm@fepagro.rs.gov.br
\end{abstract}

Abstract - The objective of this work was to identify the spectral bands, vegetation indices, and periods of the canola crop season in which the correlation between spectral data and biophysical indicators (total shoot dry matter and grain yield) is most significant. The experiment was carried out during the 2013 and 2014 crop seasons at Embrapa Trigo, in the state of Rio Grande do Sul, Brazil. A randomized complete block design was used, with four replicates, and the treatments consisted of five doses of nitrogen topdressing. Plant dry matter, grain yield, and phenology were measured. The canola spectral response was evaluated by measuring the canola canopy reflectance using a spectroradiometer, and, with this data, the SR, NDVI, EVI, SAVI, and GNDVI vegetation indices were determined. Pearson's correlations between the spectral and biophysical variables of canola showed that the red $(620$ to $670 \mathrm{~nm})$ and near-infrared (841 to $876 \mathrm{~nm}$ ) bands were the best to estimate the dry matter. The vegetative period is the most indicated to obtain the most significant correlations for canola. All the used vegetation indices are adequate for estimating the dry matter and grain yield of canola.

Index terms: Brassica napus, EVI, GNDVI, NDVI, SAVI, spectroradiometry.

\section{Correlações entre dados espectrais e biofísicos em dossel de canola cultivada na região subtropical do Brasil}

\begin{abstract}
Resumo - O objetivo deste trabalho foi a identificação das bandas espectrais, dos índices de vegetação e dos períodos do ciclo da canola em que a correlação entre os dados espectrais e os indicadores biofísicos (matéria seca total da parte aérea e rendimento de grãos) é mais significativa. Os experimentos foram conduzidos nas safras de 2013 e 2014, na Embrapa Trigo, no Estado do Rio Grande do Sul. Utilizou-se o delineamento experimental em blocos ao acaso, com quatro repetições, e os tratamentos foram cinco doses de nitrogênio em cobertura. Foram determinados a matéria seca das plantas, o rendimento de grãos e a fenologia. A resposta espectral da canola foi avaliada por medições de reflectância do dossel, com espectrorradiômetro, e, a partir desses dados, foram calculados os índices de vegetação SR, NDVI, EVI, SAVI e GNDVI. As correlações de Pearson entre as variáveis espectrais e biofísicas da canola mostraram que as melhores bandas para estimativa da matéria seca são as do vermelho $(620$ a $670 \mathrm{~nm})$ e do infravermelho próximo $(841$ a $876 \mathrm{~nm})$. O período vegetativo é o mais indicado para obtenção de correlações mais significativas para a canola. Todos os índices de vegetação utilizados são adequados para estimativas da matéria seca e do rendimento de grãos da canola.
\end{abstract}

Termos para indexação: Brassica napus, EVI, GNDVI, NDVI, SAVI, espectrorradiometria.

\section{Introduction}

Research programs should focus on grain yield, since, from an economic viewpoint, it is the most important variable to the farmer because it determines the economic return of the crop.
Grain yield can be predicted by agrometeorologicalspectral models in which the spectral variable is usually represented by vegetation indices, considered remote indicators of vegetation vigor. Theses indices are proposed based on the antagonistic response of the vegetation reflectance in the spectral regions of 
the visible and near infrared due to the accumulation of biomass (Jensen, 2009). The higher the amount of biomass, the lower the reflectance is in the visible region due to the increased absorption by the photosynthetic pigments. In the near infrared, the increased biomass causes the reflectance to increase due to increased multiple scattering and additive reflectance (Jensen, 2009; Ponzoni et al., 2012).

Agrometeorological-spectral models, with some variants in the selected terms and the type of adjusted equations, have been proposed in the literature (Rosa et al., 2010; Mabilana et al., 2012). Studies have been conducted in areas with climatic and management conditions similar to those of the present study for the following annual crops: soybean (Melo et al., 2008), irrigated rice (Klering et al., 2016), and wheat (Junges \& Fontana, 2011). Despite the importance of grain yield studies, models to estimate canola grain yields adjusted to the specific management and climate conditions of the state of Rio Grande do Sul are not yet available in the literature.

Canola (Brassica napus L. var. oleifera) has become an interesting, feasible option as a winter cereal for crop rotation in southern Brazil. Also, its high oil content in the grains generates great liquidity in the market, increasing crop demand and demand for specific knowledge regarding the culture to meet production bottlenecks and increase the crop productive efficiency in the predominant subtropical climate conditions, in Rio Grande do Sul. Although the introduction of canola in Brazil is not recent, research on this culture is still not very expressive, requiring efforts to increase the basis of information and knowledge.

It may be assumed that models similar to those used for other annual crops can also be adjusted for canola. Therefore, basic studies to identify the most relevant variables that best relate to the biophysical variables of canola must be pursued since these must be the input variables in the models.

Thus, this study aimed to model grain yield of canola, focusing on the spectral component of the agrometeorological-spectral models. The objective was to identify the spectral bands, vegetation indices, and periods of the canola crop season in which the correlation between spectral data and biophysical indicators (total shoot dry matter and grain yield) is most significant.

\section{Materials and Methods}

The experiments were conducted in the experimental area of Embrapa Trigo $\left(28^{\circ} 11^{\prime} 40^{\prime \prime} \mathrm{S}, 52^{\circ} 10^{\prime} 20^{\prime \prime} \mathrm{W}\right)$, in the municipality of Coxilha, in the state of Rio Grande do Sul, Brazil, during the 2013 and 2014 harvests. The climate of the region is Cfa type, according to Köppen's classification. The Hyola 61 canola cultivar was sown and the study followed a randomized complete block design with four replicates. The treatments consisted of five doses of nitrogen top dressing: 10, 20, 40, 80, and $160 \mathrm{~kg} \mathrm{ha}^{-1} \mathrm{~N}$ (urea, 45\% nitrogen) to characterize the different management conditions and increase the variability of the crop's spectral and biophysical responses. The previous summer crops were soybean and bean in the 2013 and 2014 crop years, respectively.

Canola was sown spaced $0.34 \mathrm{~m}$ between rows and with minimum sowing density of 40 plants per square meter on April 22, 2013 and April 29, 2014.

From the emergence of the seedlings, two paired plants, representative of the plot, were collected biweekly to determine shoot dry matter. After collection, in the laboratory, the plants were separated in leaves, branches, flowers and siliques, and then placed in a forced air circulation oven for drying until constant mass at $70^{\circ} \mathrm{C}$. Also, plant phenology was recorded every four days. The new phenological stage of the canopy/plot was defined as a stage at which at least $50 \%$ of the plants had entered that stage. Areas of 1.02 and $6 \mathrm{~m}^{2}$ per plot were manually harvested and threshed using a plot harvester (Wintersteiger, Nursery model, Austria) to determine grain yield in the 2013 and 2014 harvests, respectively. After the threshing, the grains were packed in tagged paper containers, which were placed in a forced air circulation oven for drying to a constant mass at $70^{\circ} \mathrm{C}$. After the grains were dried to a constant mass, they were sieved through for cleaning and weighed to determine dry matter and grain yield (calculated at $8 \%$ humidity).

Canola spectral response was evaluated by measuring canopy reflectance using a LI-1800 spectroradiometer (LI-COR, Lincoln, Nebraska, USA) with $2 \mathrm{~nm}$ spectral resolution, between $350 \mathrm{~nm}$ and $1,100 \mathrm{~nm}$, at $1 \mathrm{~m}$ above the top of the canopy. A barium sulfate plate $\left(\mathrm{BaSO}_{4}\right)$ was used to simulate a Lambertian surface of known reflectance as reference. Canopy reflectance was given as the ratio between the energy reflected by the canopy and by the reference plate. The measurements were performed on clear 
sky, cloud free days to ensure similar illumination and observation conditions, and always around noon to maximize solar elevation in the area and season of the year. Reflectance per plot was measured on the seven following dates: $7 / 15,7 / 30,8 / 15,8 / 30,9 / 13,9 / 26$, and $11 / 5$ in 2013 ; and 5/20, 6/4, 7/15, 8/5, 8/19, 9/9, and $9 / 22$ in 2014. Canopy reflectance data were used to calculate the vegetation indices (Jensen, 2009): simple ratio (SR), normalized difference vegetation index (NDVI), enhanced vegetation index (EVI), soil-adjusted vegetation index (SAVI), and green normalized difference vegetation index (GNDVI), as follows:

$$
\begin{aligned}
& \mathrm{SR}=\rho_{\text {nir }} / \rho_{\mathrm{r}} ; \mathrm{NDVI}=\left(\rho_{\text {nir }}-\rho_{\mathrm{r}}\right) /\left(\rho_{\text {nir }}+\rho_{\mathrm{r}}\right) ; \\
& \mathrm{EVI}=\mathrm{G}\left(\rho_{\text {nir }}-\rho_{\mathrm{r}}\right) /\left(\mathrm{L}+\rho_{\text {nir }}+\mathrm{C} 1 \rho_{\mathrm{r}}+\mathrm{C} 2 \rho_{\mathrm{b}}\right) ; \\
& \mathrm{SAVI}=\left[\left(\rho_{\text {nir }}-\rho_{\mathrm{r}}\right) /\left(\rho_{\text {nir }}+\rho_{\mathrm{r}}+\mathrm{L}\right)\right](1+\mathrm{L}) ; \text { and } \\
& \mathrm{GNDVI}=\left(\rho_{\text {nir }}-\rho_{\mathrm{g}}\right) /\left(\rho_{\text {nir }}+\rho_{\mathrm{g}}\right) ;
\end{aligned}
$$

in which: $\rho_{\text {nir }}, \rho_{\mathrm{r}}, \rho_{\mathrm{g}}$, and $\rho_{\mathrm{b}}$ are the reflectances in the near infrared (841 to $876 \mathrm{~nm})$, red $(620$ to $670 \mathrm{~nm})$, green (545 to $565 \mathrm{~nm}$ ), and blue (459 to $479 \mathrm{~nm}$ ), respectively; $\mathrm{L}$ is the constant that minimizes soil effect $(\mathrm{L}=1) ; G$, gain factor $(\mathrm{G}=2.5) ; \mathrm{C} 1$ and $\mathrm{C} 2$, the adjustment factors to correct for atmospheric aerosols $(\mathrm{C} 1=6.5$ and $\mathrm{C} 2=7.5)$.

The spectral bands used to compute the vegetation indices were made compatible with the moderate resolution imaging spectroradiometer (Modis) sensor band width and sensitivity by applying a filter function obtained from the spectral library of the ENVI 5.0 software (Exelis, 2016). Therefore, the reflectance data were multiplied by the filter function values for each wavelength and, then, the band mean was calculated. This compatibilization aimed at allowing subsequent comparisons with orbital data.

The total shoot dry matter and grain yield data of canola were subjected to the analysis of variance, at $5 \%$ probability, while the model included the fixed effects of block, treatment, year, and treatment $\mathrm{x}$ year interaction. The total shoot dry matter evaluations performed throughout 2013 and 2014 were considered as measures repeated in the time. The treatment means were compared by Tukey's test, at $5 \%$ probability. The data obtained in the two harvests were treated as a single dataset separated into three crop cycles: vegetative, flowering and maturation. Then, Pearson's correlations were established between: the shoot dry matter accumulated and the reflectance in the blue, green, red and near-infrared bands; total shoot dry matter and vegetation indices; and grain yield and vegetation indices. The maximum vegetation index (maximum value obtained in the cycle) and the sum of all vegetation indices (summation of the values obtained in the cycle) were correlated with grain yield. Pearson correlations were tested by Student's t-test, at $1 \%$ probability.

\section{Results and Discussion}

The different nitrogen treatments and the evaluations over two harvesting periods, with different meteorological conditions, promoted the expected variability of the crop biophysical indicators. Total shoot dry matter and grain yield varied significantly, which allowed correlation analyses.

The accumulated shoot dry matter was higher for all treatments in the 2013 crop year compared with 2014 (Table 1). The values of this biophysical indicator were significantly different between the doses of topdressing nitrogen fertilization treatments, and higher for the $160 \mathrm{~kg} \mathrm{ha}^{-1} \mathrm{~N}$ in comparison with 10 and $20 \mathrm{~kg} \mathrm{ha}^{-1}$ treatments for both harvests (Table 1).

Grain yield was also significantly higher in 2013 compared with 2014 crop year, which varied between 2,595.79 $\mathrm{kg} \mathrm{ha}^{-1}\left(10 \mathrm{~kg} \mathrm{~N} \mathrm{ha}{ }^{-1}\right)$ and 4,029.98 $\mathrm{kg} \mathrm{ha}^{-1}$ $\left(80 \mathrm{~kg} \mathrm{~N} \mathrm{ha}^{-1}\right)$ in 2013 , and $1,129.81 \mathrm{~kg} \mathrm{ha}^{-1}\left(10 \mathrm{~kg} \mathrm{~N} \mathrm{ha}^{-1}\right)$ and $1,552.69 \mathrm{~kg} \mathrm{ha}^{-1}\left(80 \mathrm{~kg} \mathrm{~N} \mathrm{ha}^{-1}\right)$ in 2014. The pattern found is similar to the results found by Kaefer et al. (2014), who subjected canola plants to increasing doses of nitrogen fertilization and reported increased grain yield. The higher grain yield in the 2013 crop year was expected, due to the differences observed in the shoot dry matter between the two harvests.

The different values of shoot dry matter accumulation and grain yield between the two harvests can be attributed especially to different meteorological conditions during the crop growth cycle. The lower air temperature in the 2013 crop year, compared with 2014 crop year, favored plant growth and acclimatization. Dalmago et al. (2009) stated that the canola cultivated in southern Brazil does not require vernalization, but it develops better in mild average air temperatures. The acclimatization of canola plants to low temperatures consists of a series of physiological, molecular and biochemical changes, including increased leaf thickness (Rapacz, 1999). The 
higher air temperatures in 2014 accelerated the canola growth cycle, which resulted in lower growth and consequently lower accumulation of shoot dry matter (Pinto et al., 2017).

The spectroradiometer measurements also showed higher accumulated shoot dry matter in 2013, which displayed a different pattern throughout the electromagnetic spectrum. In the two harvests, the reflectance (Figure 1) increased in the red, yellow and green bands from the vegetative period until flowering, and decreased during the grain filling period. On the contrary, in the blue band, the spectral reflectance decreased from the vegetative to the flowering period, and increased during grain filling. In the near infrared, the reflectance decreased steadily from the vegetative period to the end of the cycle.

Despite the similar spectral reflectance patterns of the two harvests (Figure 1), the reflectance in the red and yellow bands was lower in 2014, in comparison with the reflectance in 2013, in the flowering period, and the reflectance was higher in the vegetative and grain filling periods in 2014 in comparison with 2013. In the vegetative and grain filling periods, in 2013, canola had greater biomass yield, which absorbed more radiation in the red and yellow bands for the photosynthesis processes, compared with 2014. During the flowering periods, the reflectance increased less in 2014 than in 2013, possibly indicating that in 2014 there were fewer flowers in the canopy, which reflected more radiation in the visible bands.

The higher shoot dry matter (Table 1) in 2013 resulted in higher vegetation indices compared with 2014 (Figure 2), as shown by the position of the box plots and the median values. This result was expected since several studies have shown that vegetation indices are indicators of green vegetation activity (Jensen, 2009; Monteiro et al., 2012; Ponzoni et al., 2012). The vegetation activity includes leaf area index (LAI), green coverage, chlorophyll content, green biomass,

Table 1. Accumulated shoot dry matter (DM) $\left(\mathrm{g} \mathrm{m}^{-2}\right)$ and grain yield $\left(\mathrm{kg} \mathrm{ha}^{-1}\right)$ for the studied nitrogen topdressing doses (urea, $\mathrm{kg} \mathrm{ha}^{-1}$ ) applied to canola (Brassica napus) crop in the 2013 and 2014 harvests ${ }^{(1)}$ in municipality of Coxilha, state of Rio Grande do Sul, Brazil.

\begin{tabular}{|c|c|c|c|c|c|c|}
\hline \multirow[t]{2}{*}{ Harvest } & & \multicolumn{5}{|c|}{ Nitrogen doses } \\
\hline & & 10 & 20 & 40 & 80 & 160 \\
\hline \multirow{2}{*}{2013} & Total DM & $1,070.89 \mathrm{Ba}$ & $1,063.08 \mathrm{Ba}$ & $1,147.33 \mathrm{ABa}$ & $1,162.71 \mathrm{ABa}$ & $1,241.32 \mathrm{Aa}$ \\
\hline & Grain yield & $2,595.79 \mathrm{Ba}$ & $3,325.39 \mathrm{ABa}$ & $3,054.66 \mathrm{ABa}$ & 4,029.98Aa & $3,091.52 \mathrm{ABa}$ \\
\hline \multirow{2}{*}{2014} & Total DM & $573.38 \mathrm{Bb}$ & $543.91 \mathrm{Bb}$ & $585.05 \mathrm{ABb}$ & $670.45 \mathrm{ABb}$ & $713.77 \mathrm{Ab}$ \\
\hline & Grain yield & $1,129.81 \mathrm{Bb}$ & $1,275.14 \mathrm{ABb}$ & $1,401.51 \mathrm{ABb}$ & $1,552.69 \mathrm{Ab}$ & $1,461.96 \mathrm{ABb}$ \\
\hline
\end{tabular}

${ }^{(1)}$ Means followed by equal letters, uppercase in the rows and lowercase in the columns, do not differ by Tukey's test, at $5 \%$ probability.

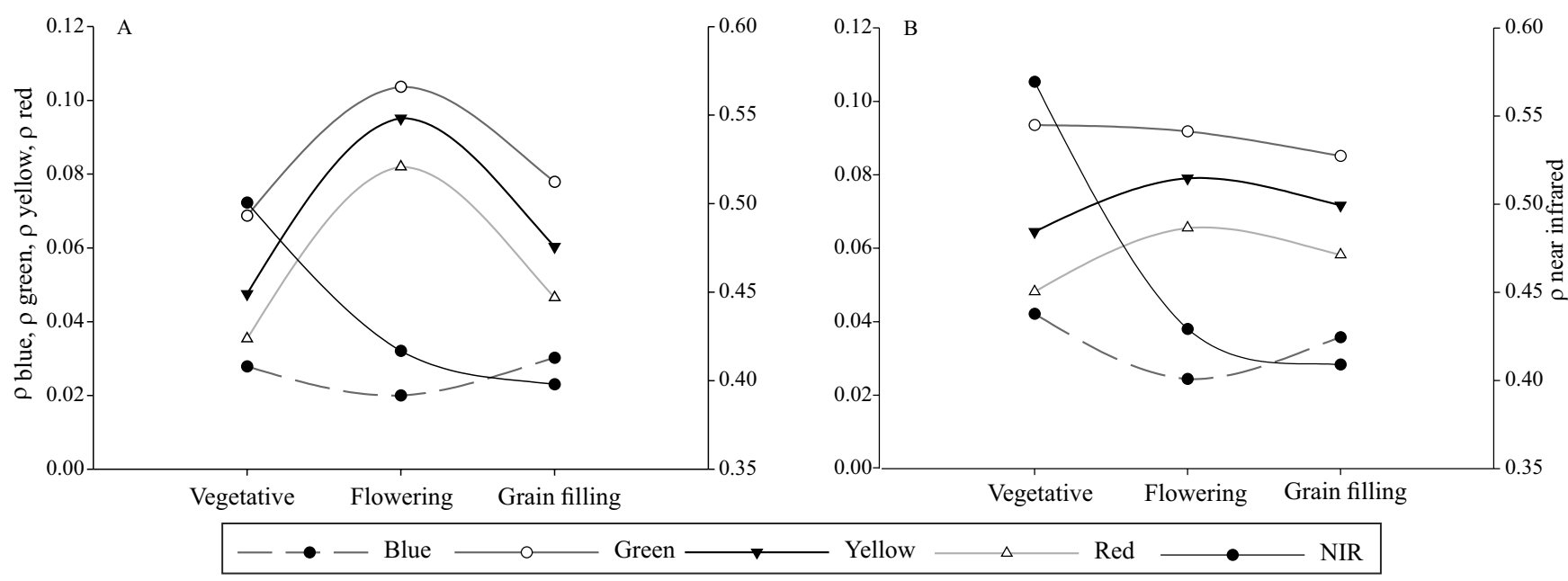

Figure 1. Spectral reflectance in the blue ( $\rho$ blue), green ( $\rho$ green), yellow ( $\rho$ yellow), red ( $\rho$ red), and near infrared ( $\rho$ near infrared - NIR) bands for the three developmental stages of canola (Brassica napus): vegetative, flowering, and grain filling, in the 2013 (A) and 2014 (B) harvests in municipality of Coxilha, state of Rio Grande do Sul, Brazil. 
and photosynthetically absorbed active radiation (Jensen, 2009). Furthermore, greater variability of the vegetation indices was also observed in 2014.

In the vegetative period, Pearson's correlation coefficients (r) between the accumulated total shoot dry matter and the reflectance levels of the spectral bands analyzed (Figure 3) were negative and significant in the blue (-0.63) and red (-0.80) bands, negative and nonsignificant in the green $(-0.25)$, and positive and significant in the near-infrared (0.76) ones.

The observed data pattern is consistent with the current knowledge on the interaction between solar radiation and the dense and green vegetative canopy. The higher the biomass in the canopy during the cycle, the lower the electromagnetic radiation (REM) reflectance is in the visible bands, due to the greater amount of photosynthesizing pigments absorbing the radiation to carry out photosynthesis (Ponzoni et al., 2012), which resulted in negative correlation coefficients. The correlation coefficient was not significant in the green band because photosynthetic pigments do not absorb the solar radiation in this band, thus determining the reflectance peak in the green band in the typical vegetation reflectance curves (Jensen, 2009). The opposite of the blue and red bands was observed in the near infrared, that is, the higher the biomass in the canopy, the greater the REM reflectance was, which resulted in positive correlation coefficients. It is noteworthy that the red and near infrared bands are widely used to calculate vegetation indices because they are the most well correlated with green biomass. Monteiro et al. (2012) correlated the LAI with hyperspectral data in a bean crop and reported negative correlations between the LAI and the bands at the visible wavelengths, and positive bands at the near infrared wavelengths.

During flowering, the correlation coefficients were negative in the blue $(-0.23)$ and near infrared $(-0.40)$ bands, and positive in the green (0.40) and red (0.46) bands, but not statistically significant (Figure 3). Positive coefficients indicated that both reflectance and shoot dry matter of canola increased as result of a large amount of inflorescences in the canopy during canola flowering, which reflected part of the visible radiation, increasing this band reflectance. According to Thomas (2003), in the flowering peak, canola produces a layer of flowers about $30-\mathrm{cm}$ thick, which can reflect the visible electromagnetic radiation, reducing the amount of solar radiation that could be used by photosynthetically active plant structures of the plant. In the near infrared, the correlation coefficient was negative, possibly due to the lower reflectance at these wavelengths, because the leaves were below the flower layer, with less interaction with REM.

Reflectance and biomass were not correlated at maturation, and the correlation coefficients were lower than the previous ones and were not statistically significant (Figure 3). At this stage, reflectance and biomass are not expected to have good correlation coefficients, since the plants are in the grain filling stage, with translocation of photoassimilates from the photosynthesizing organs (sources) to organs that
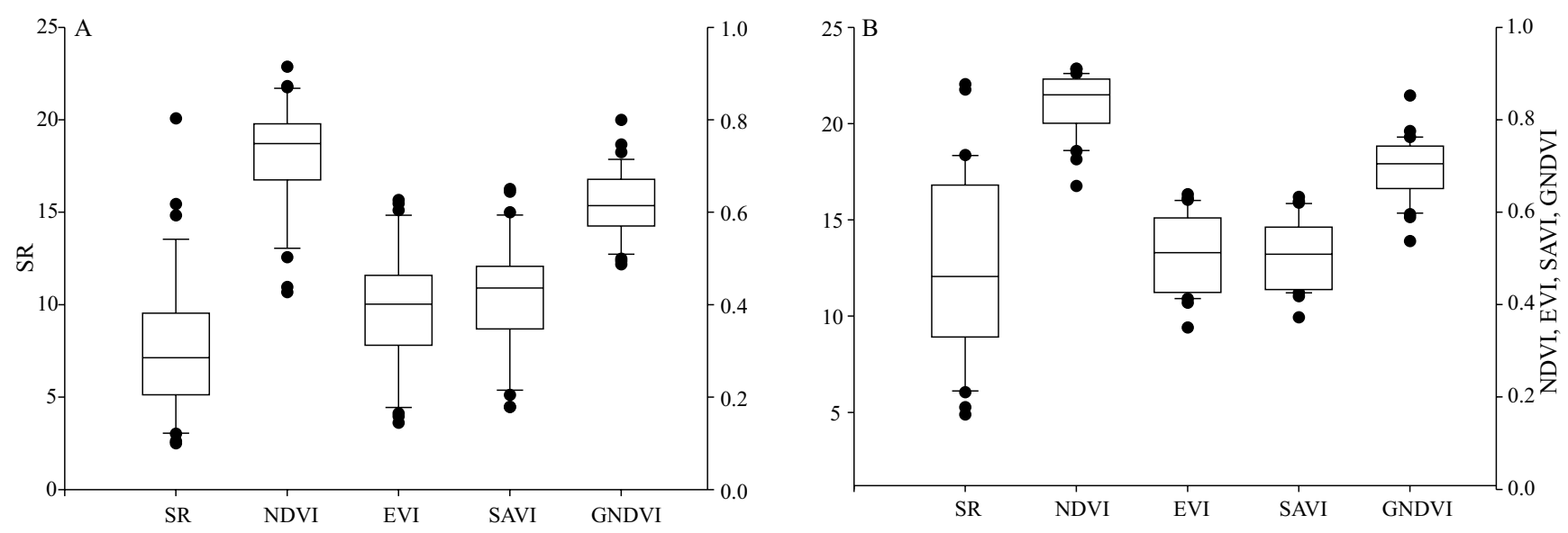

Figure 2. Box plots of the normalized difference vegetation index (NDVI), enhanced vegetation index (EVI), soil adjusted vegetation index (SAVI), green normalized difference vegetation index (GNDVI), and simple ratio (SR) for canola (Brassica napus) in the 2013 (A) and 2014 (B) harvests in municipality of Coxilha, state of Rio Grande do Sul, Brazil. 
do not perform photosynthesis, the grains (drains) (Slewinski \& Braun, 2010). The plants enter the senescence process during this stage, increasing the

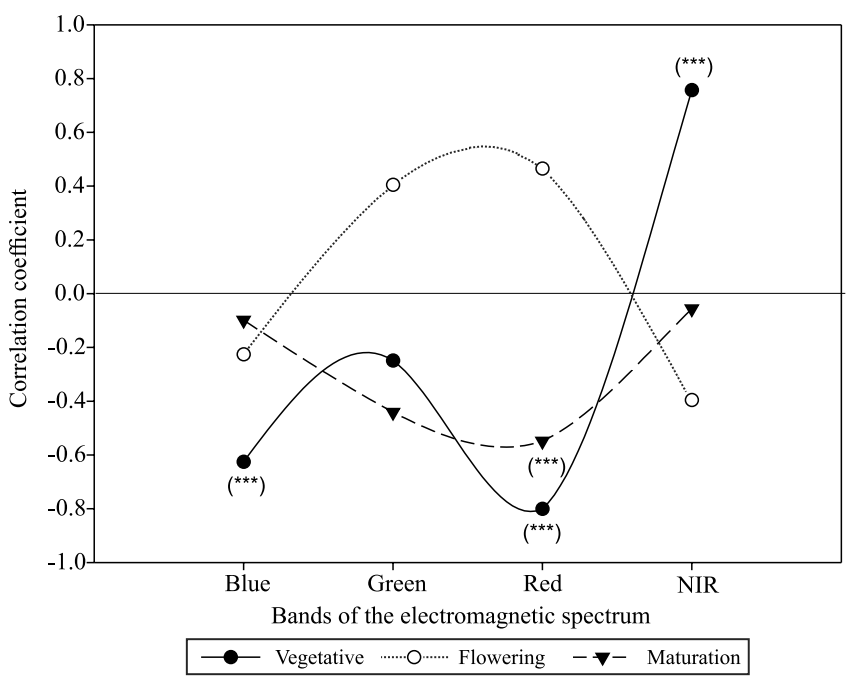

Figure 3. Pearson's correlation coefficients between the shoot dry matter of canola and the reflectance of electromagnetic radiation in the blue, green, red and nearinfrared bands of the electromagnetic spectrum, in the following developmental stages: vegetative, flowering, and maturation - harvests of 2013 and 2014, in the municipality of Coxilha, in the state of Rio Grande do Sul, Brazil. ***Significant at $1 \%$ probability.

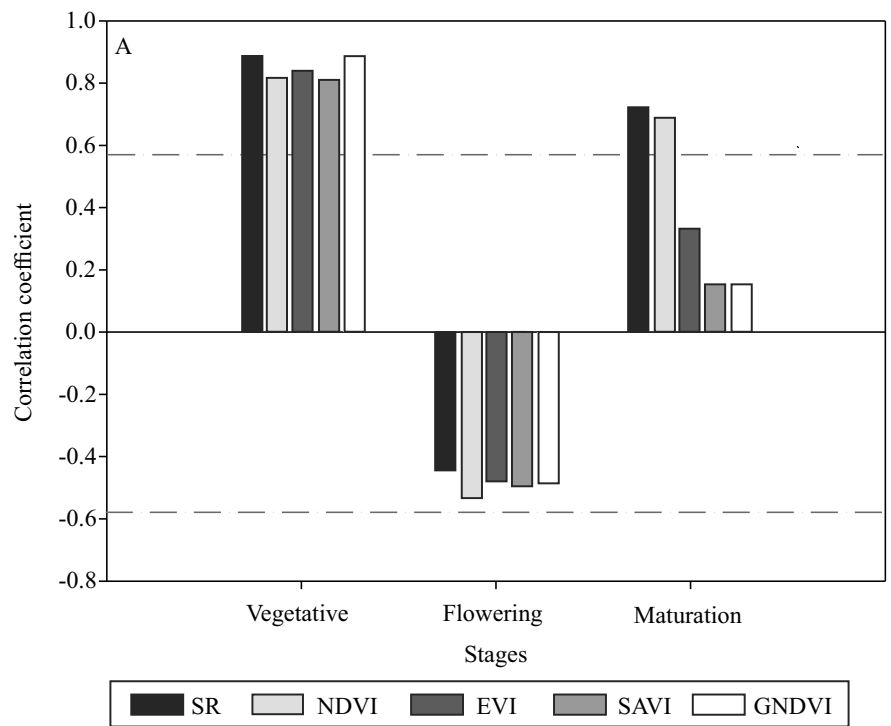

variability of the relationship between incident and reflected solar radiation.

Positive and statistically significant correlation values were observed between all vegetation indices (SR, NDVI, EVI, SAVI, and GNDVI) and shoot dry matter of canola (Figure $4 \mathrm{~A}$ ), in the vegetative period. In contrast to it, the correlation coefficients were negative and not statistically significant for all vegetation indices during flowering. In the maturation period, correlation coefficients were again positive for all vegetation indices, but statistically significant only for the SR and NDVI indices.

The higher correlations between the vegetation indices and shoot dry matter in the vegetative period were expected since, in this period, the plant biomass in the canopy increases through the photosynthetic process, and the vegetation indices are known to be highly correlated with the chlorophyll content and green biomass (Jensen, 2009). Negative correlation coefficients during flowering were due to the slightly increased or even unchanged total plant biomass, and decreased vegetation indices. This decrease can be attributed to the increased reflectance in the visible bands caused by the flowers, as already mentioned. During maturation, the correlation coefficients were again positive, as both total biomass and vegetation

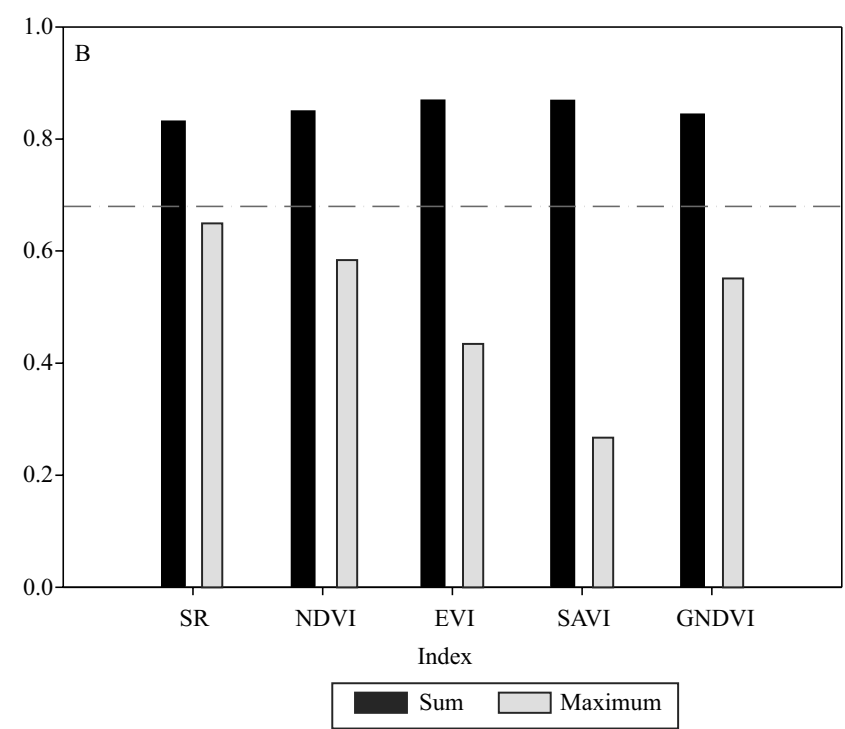

Figure 4. Pearson's correlation coefficients between canola (Brassica napus) total dry matter and the vegetation indices simple ratio (SR), normalized difference vegetation index (NDVI), enhanced vegetation index (EVI), soil adjusted vegetation index (SAVI), and green normalized difference vegetation index (GNDVI) in the following stages: vegetative, flowering, and maturation (A); and Pearson's correlation coefficients between canola grain yield and the following vegetation indices: SR, NDVI, EVI, Savi, and GNDVI (B) - harvests of 2013 and 2014, in the municipality of Coxilha, in the state of Rio Grande do Sul, Brazil. The dashed lines show significant correlations at $1 \%$ probability. 
indices decreased. However, the coefficients were lower than those in the vegetative period. The flower petals usually fall during maturation, but interception and absorption of photosynthetically active radiation (PAR) by siliques and stems may continue. Fochesatto et al. (2016) evaluated the interception efficiency of PAR by canola reproductive structures and stems for five nitrogen doses $\left(10,20,40,80\right.$, and $\left.160 \mathrm{~kg} \mathrm{ha}^{-1} \mathrm{~N}\right)$ and reported that the efficiency of PAR interception by the reproductive structures and stems of the canola canopy can reach $70 \%$ of the total canopy interception in the plots treated with $160 \mathrm{~kg} \mathrm{ha}^{-1} \mathrm{~N}$.

Therefore, intrinsic characteristics of the canola crop, such as the intense flowering and the existence of photosynthesizing structures besides the leaves, make the interaction between the crop and solar radiation, as well as its detection by remote sensors, very specific. These characteristics are important and should be taken into account both for the differentiation of other crops and for the construction of grain yield estimation models.

The grain yield and vegetation indices had positive correlation coefficients for both analyzed parameters (the maximum value of vegetation index during the cycle and the sum of all vegetation indices in the same period) (Figure 4 B). However, the correlation coefficients between grain yield and the sum of all vegetation indices in the cycle were similar and statistically significant for all vegetation indices, and higher than the correlation coefficients of grain yield with the maximum vegetation index, which were not statistically significant. This pattern is consistent because the sum of all vegetation indices is related to the development of biomass during the development cycle. Despite being related to higher biomass accumulation, the maximum vegetation index is limited by the saturation of vegetation indices, more evident in some indices such as NDVI in high biomass values (Risso et al., 2012).

The vegetation indices, expressed from parameters derived from reflectance curves - the maximum vegetation index during the cycle and the sum of all vegetation indices in the same period -, have been widely used, especially in the context of grain yield modeling. Junges (2011) found positive correlations between the maximum and the integrated NDVI, for wheat grain yield in Rio Grande do Sul. Similarly, Rodrigues et al. (2013) associated vegetation indices and absorption of atmospheric $\mathrm{CO}_{2}$, which is useful in the context of climate change discussions.

There is, therefore, a correlation between the spectral data (vegetation indices) and the biophysical data of the canola (which reflect plant biomass growth), allowing the use of these spectral data to feed spectral or agrometeorological-spectral models of grain yield and biomass increase.

\section{Conclusions}

1. The most indicated spectral bands to obtain the most significant correlations for canola (Brassica napus) are the red and near-infrared, while the vegetative cycle is the most appropriate phenological stage, under subtropical climate conditions.

2. The vegetation indices SR, NDVI, EVI, SAVI, and GNDVI are appropriate to represent the total shoot dry matter and the grain yield of canola.

3. The best results for grain yield estimation using vegetation indices are obtained by summing all the index values recorded during the canola cycle.

\section{Acknowledgments}

To Universidade Federal do Rio Grande do Sul (UFRGS), to Embrapa Trigo, and to Conselho Nacional de Desenvolvimento Científico e Tecnológico (CNPq), for the support provided.

\section{References}

DALMAGO, G.A.; CUNHA, G.R. da; TOMM, G.O.; SANTI, A.; PIRES, J.L.F. Canola. In: MONTEIRO, J.E.B.A. (Org.). Agrometeorologia dos cultivos: o fator meteorológico na produção agrícola. Brasília: INMET, 2009. p.131-150.

EXELIS. Spectral Library Viewer. Available at: <http://www. exelisvis.com/docs/SpectralLibBrowser.html>. Accessed on: Apr. 242016.

FOCHESATTO, E.; NIED, A.H.; BERGAMASCHI, H.; DALMAGO, G.A.; PINTO, D.G.; KOVALESKI, S.; CUNHA, G.R. da; GOUVEA, J.A. Interception of solar radiation by the productive structures of spring canola hybrids. Ciência Rural, v.46, p.1790-1796, 2016. DOI: 10.1590/0103-8478cr20151571.

JENSEN, J.R. Sensoriamento remoto do ambiente: uma perspectiva em recursos terrestres. 2.ed. São José dos Campos: Parêntese, 2009. 598p.

JUNGES, A.H.; FONTANA, D.C. Modelo agrometeorológicoespectral de estimativa de rendimento de grãos de trigo no Rio Grande do Sul. Revista Ceres, v.58, p.9-16, 2011. DOI: 10.1590/ S0034-737X2011000100002. 
KAEFER, J.E.; GUIMARÃES, V.F.; RICHART, A.; TOMM, G.O.; MÜLLER, A.L. Produtividade de grãos e componentes de produção da canola de acordo com fontes e doses de nitrogênio. Pesquisa Agropecuária Brasileira, v.49, p.273-280, 2014. DOI: 10.1590/S0100-204X2014000400005.

KLERING, E.V.; FONTANA, D.C.; ROGLIO, V.S.; ALVES, R. de C.M.; BERLATO, M.A. Modelo agrometeorológico-espectral para estimativa da produtividade de grãos de arroz irrigado no Rio Grande do Sul. Bragantia, v.75, p.247-256, 2016. DOI: 10.1590/1678-4499.287.

MABILANA, H.A.; FONTANA, D.C.; FONSECA, E.L. da. Desenvolvimento de modelo agrometeorológico espectral para estimativa de rendimento do milho na Província de Manica Moçambique. Revista Ceres, v.59, p.337-349, 2012. DOI: 10.1590/ S0034-737X2012000300007.

MELO, R.W. de; FONTANA, D.C.; BERLATO, M.A.; DUCATI, J.R. An agrometeorological-spectral model to estimate soybean yield, applied to southern Brazil. International Journal of Remote Sensing, v.29, p.4013-4028, 2008. DOI: 10.1080/01431160701881905.

MONTEIRO, P.F.C.; ANGULO FILHO, R.; XAVIER, A.C.; MONTEIRO, R.O.C. Assessing biophysical variable parameters of bean crop with hyperspectral measurements. Scientia Agricola, v.69, p.87-94, 2012. DOI: 10.1590/S010390162012000200001.

PINTO, D.G.; FONTANA, D.C.; DALMAGO, G.A.; CUNHA, G.R. da; FOCHESATO, E.; VICARI, M.B.; GOUVÊA, J.A. de; SANTI, A. Temporal dynamics of spectral reflectance and vegetation indices during the canola crop cycle in southern
Brazil. Ciência Rural, v.47, e20151403, 2017. DOI: 10.1590/0103$8478 \mathrm{cr} 20151403$.

PONZONI, F.J.; SHIMABUKURO, Y.E.; KUPLICH, T.M. Sensoriamento remoto da vegetação. 2.ed. atual e ampl. Cubatão: Oficina de Textos, 2012. 160p.

RAPACZ, M. Frost resistance and cold acclimation abilities of spring-type oilseed rape. Plant Science, v.147, p.55-64, 1999. DOI: 10.1016/S0168-9452(99)00098-9.

RISSO, J.; RIZZI, R.; RUDORFF, B.F.T.; ADAMI, M.; SHIMABUKURO, Y.E.; FORMAGGIO, A.R.; EPIPHANIO, R.D.V. Índices de vegetação Modis aplicados na discriminação de áreas de soja. Pesquisa Agropecuária Brasileira, v.47, p.13171326, 2012. DOI: 10.1590/S0100-204X2012000900017.

RODRIGUES, C.P.; FONTANA, D.C.; MORAES, O.L.L. de; ROBERTI, D.R. NDVI e fluxo de $\mathrm{CO}_{2}$ em lavouras de soja no Rio Grande do Sul. Revista Brasileira de Meteorologia, v.28, p.95104, 2013. DOI: 10.1590/S0102-77862013000100011.

ROSA, V.G.C. da; MOREIRA, M.A.; RUDORFF, B.F.T.; ADAMI, M. Estimativa da produtividade de café com base em um modelo agrometeorológico-espectral. Pesquisa Agropecuária Brasileira, v.45, p.1478-1488, 2010. DOI: 10.1590/S0100204X2010001200020.

SLEWINSKI, T.L.; BRAUN, D.M. Current perspectives on the regulation of whole-plant carbohydrate partitioning. Plant Science, v.178, p.341-349, 2010. DOI: 10.1016/j.plantsci.2010.01.010.

THOMAS, P. Canola: grower's manual. Winnipeg: Canola Council of Canada, 2003. Available at: $<$ http://www.canolacouncil.org/cropproduction/canola-grower's-manual-contents/chapter-2-canolavarieties/canola-varieties\#brassica>. Accessed on: Aug. 52013.

Received on September 29, 2016 and accepted on March 2, 2017 